Przegląd Badań Edukacyjnych

ISSN 1895-4308

nr $18(1 / 2014)$, s. $115-124$

METAANALIZY

BADAŃ

EDUKACYJNYCH

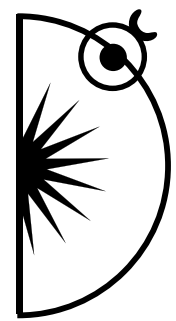

Andrzej Wojciechowski

\title{
Poznanie przez upodobnienie jako wejście w model Davida Silvermana*
}

DOI: http://dx.doi.org/10.12775/PBE.2014.009

David Silverman przedstawia nam perspektywę metodologiczną opartą na przekonaniu, iż ,nie istnieje neutralny problem badawczy”. Zawsze odzwierciedla on „przywiązanie (jawne bądź ukryte) badacza do określonego modelu opisującego funkcjonowanie świata" (Silverman 2012b:28). To jedno.

Za Watsonem, Emisson, McHoul i Priorem stwierdza zaś, że świat poznajemy „w zależności od sposobu, w jaki jest reprezentowany” (Silverman 2012a; s. 218)

Tak więc mamy tu już dwa ograniczenia naszych procesów poznawczych:

- Ograniczenie wynikające z tego, o czym pisze O. J. M. Bocheński: wiedza jest czymś, „co można odnaleźć w duszy i tylko w niej [...] jest ona dla nas pewnym stanem [...] jest ona mianowicie tym, dzięki czemu jakiś człowiek zostaje nazwany wiedzacym [...] każda wiedza jest wiedzą indywidualnego człowieka. (Bocheński: 14). Więc ograniczenie określane przez samo istnienie badacza.

- Ograniczenie wynikające $\mathrm{z}$ „możliwości postrzegania reprezentacji świata”.

* Referat wygłoszony na I Seminarium Metodologii Pedagogiki Specjalnej - Ogród wieloparadygmatyczności w badaniach nad niepełnosprawnością, Katedra Pedagogiki Rehabilitacji i Resocjalizacji Wydziału Nauk Pedagogicznych UMK w Toruniu, 3 grudnia 2013 r. 
Najciekawszą dla mnie metaforą tego jest przywołana przez Silvermana metafora „atlasu wszechświata” Lindsaya Priora (Silverman 2012a; s. 218). W takim naszym atlasie mamy reprezentacje konstelacji gwiezdnych. Lecz, jak zwraca uwagę Prior, „te konstelacje są wytworem czysto ludzkim, ponieważ istnieją tylko w annałach ludzkiej kultury". Warto się przy tym nieco zatrzymać. Rzeczywiście obserwowany przez nas z Ziemi obszar „firmamentu niebieskiego" jest strukturą względnie stabilną, wręcz, przez niezliczone wieki, uważano, że szczególnie stabilną. Obserwowano wzajemne relacje zarówno świecących ciał niebieskich do samych siebie, jak i do obserwatora. Uznano, że są to relacje stałe. Tak dalece stałe, że dzięki nim skonstruowano precyzyjne narzędzia umożliwiające np. nawigację w różnych obszarach Ziemi. Można wręcz powiedzieć, że zbudowano w odniesieniu do tego ,ustalonego firmamentu" cały kształt cywilizacji.

Jednak to jest tylko projekcja punktów świecących rozmieszczonych także w głąb wobec siebie, na płaski ekran naszego postrzeganego obrazu. Teraz już doskonale wiemy, że to jest ważne tylko dla obserwatora z Ziemi. Dla obserwatora wysłanego w kosmos konstelacje te po prostu znikną. Rzeczywista była tylko projekcja ich obrazu na sferę postrzegania obserwatora z Ziemi. Jednak wiemy, że odejście od tego w końcu statycznego obrazu wymagało ODWAGI OBSERWATORA. Nie jakiegoś tam, ale konkretnego człowieka, który miał przesłanki do podjęcia tego odważnego kroku. Myślę o Koperniku. Mówiąc o nim, jakby marginalizuje się to, że był wykształconym teologiem i człowiekiem wierzącym. Sądzę, że właśnie to pozwoliło mu wyjść od przesądu Uniwersum ustabilizowanego w obrazie do Uniwersum ustabilizowanego w mądrości Stwórcy wykraczającej poza Ziemię.

Idąc za tym, powinniśmy, sądzę, zawsze przyjąć, że poznane i przyjęte przez nas teorie są tylko pewnym etapem ku poznaniu rzeczywistej dynamiki danych. Odnosząc się do myśli Kirka i Millera (Silverman 2012a; s. 244) Silverman podkreśla, że „musimy zrozumieć, że świat nie akceptuje $w$ równym stopniu wszystkich nadawanych mu znaczeń. Oznacza to, że powinniśmy przezwyciężyć pokusę wyciągania łatwych wniosków tylko dlatego, że istnieja pewne dowody, które zdają się prowadzić w interesującym nas kierunku" (Silverman 2012a; s. 244).

To wszystko musi odnieść nas do teorii poznania. Rolę podstawową w niej odgrywa pojęcie ,podmiot”. Poznajemy podmioty i sami jesteśmy podmiotem poznającym. Dlaczego tak? Ano dlatego, że jesteśmy pośród nauk humanistycznych. W pedagogice człowiek poznaje człowieka. Przyjmując perspektywę tomistyczną, Jacques Maritain zwraca naszą uwagę na ,podmioty wraz z nieroz- 
łącznie z nimi związanymi przypadłościami, pochodzącym od nich działaniem i związkami, które między nimi zachodzą" (Maritain 1988a; s. 81). Tutaj od razu napotykamy te dwa ograniczenia, o których wspomniałem na początku: „ograniczenie wynikające ze struktury psychicznej badacza” i „ograniczenie wynikające z możliwości postrzegania reprezentacji świata".

„Każdy z tych podmiotów, pisze Maritain, w swojej odrębnej istniejącej rzeczywistości jest dla nas niewyczerpalną głębią poznawalności. Nigdy nie poznamy do końca tego, co kryje się w najdrobniejszym źdźble trawy czy w najmniejszym wirze strumyka. W świecie bytów są tylko podmioty, czyli supposita, $\mathrm{i}$ to, co $\mathrm{z}$ nich emanuje $\mathrm{w}$ istnienie; dlatego jest to świat przyrody i przygody, świat wydarzeń i przypadkowości, w którym bieg wypadków jest zmienny, podczas gdy prawa bytu są konieczne. Poznajemy te podmioty i nigdy nie poznamy ich do końca” (Maritain 1988a; s. 84). Ale „w miarę jak przechodzimy ku wyższym stopniom na drabinie bytów, pisze Maritain, napotykamy podmioty istnienia, supposita coraz to bogatsze w swej wewnętrznej złożoności, których indywidualność jest coraz bardziej skoncentrowana i zintegrowana [...]. W człowieku [...] suppositum staje się persona (osoba) - całością, która subsustuje i egzystuje na mocy samej substancji i egzystencji swej duchowej duszy i która działa stwarzając sama przed sobą cele [...]. Człowiek [...] jest tym, co w przyrodzie najszlachetniejsze i najbardziej wzniosłe (Maritain 1988a; s. 84/85).

Tak więc poznajemy świat otaczających nas „podmiotów, suppositów i osób w ich roli przedmiotów (poznania)".

Jedno jest tutaj bardzo ważne: my, którzy poznajemy, znajdujemy się „dokładnie pośrodku tego świat, każdy (z nas poznających) jest środkiem nieskończoności" (Maritain 1988a; s. 85).

Banalnie proste, a jak zaskakujące.

Podmiot poznający i podmioty poznawane

Kolejna trudność, bo, pisze Maritain „podmiotowość jako podmiotowość nie daje się określić jako pojęcie, jest niepoznawalną otchłanią. [...] Podmiotowość jako taka z samej definicji wymyka się temu, co poznajemy na drodze pojęć o sobie samych" (Maritain 1988a; s. 86).

Najpierw podmiotowość nas samych „będących pośrodku świata poznawanego”. „Gdy człowiek, pisze Maritain, choćby najbardziej powierzchowny powie: ja, od tej chwili podstawą rozwoju jego stanów świadomości, jego działań, marzeń, wspomnień, czynów staje się wirtualna i niewypowiedziana, egzystencjalna i żywotna świadomość całości immanentnej w każdej jej części; nie próbując zdawać sobie z tego sprawy, skąpany jest w rozproszonym świetle [...]" (Maritain 1988a; s. 87). 
Podmioty poznawane. Niestety, ich podmiotowość, a więc ich pełnia, także dla nich samych niejasna, jest dla nas nieprzekraczalna. Czy więc takie poznanie niepełne „niesprawiedliwe”, jak gdzie indziej pisze Maritain (Maritain 1988a; s. 92), jest uprawnione poznawczo, naukowo? I znów odpowiada Maritain: „nie popełnimy wobec podmiotu zdrady, ujmując go jako przedmiot; uprzedmiotowienie, uogólniając go i dostrzegając w nim natury poznawalne, pozwala go poznać poznaniem, które niewątpliwie będzie się jeszcze pogłębiało, lecz w żaden sposób nie jest niesprawiedliwe. Poznanie takie nie zniekształca prawdy o podmiocie, lecz uobecnia tę prawdę rozumowi" (Maritain 1988a; s. 95).

Lecz jednak chcielibyśmy pójść dalej, głębiej w naszym poznaniu. I znów Maritain pomaga: „dopiero miłość znosi tę niemożliwość poznania drugiego człowieka inaczej niż jako przedmiot" (Maritain 1988a; s. 97).

Miłość to upodobnienie (patrz tu Gogacz 1991). Więc Maritain wprowadza nas w przestrzeń POZNANIA PRZEZ UPODOBNIENIE:

- Poznanie przez upodobnienie afektywne;

- Poznanie przez upodobnienie umystowe;

- Poznanie poetyckie;

- Poznanie przez upodobnienie do rzeczywistości jako niedajacej się ująć w pojęcia.

Poznanie przez upodobnienie afektywne jest ,poznaniem w porządku praktycznym i etycznym. Jest to poznanie przez afektywne, skłonnościowe upodobnienie do celów działania ludzkiego, które jest sednem poznania kierowanego rozwaga" (Maritain 1988b; s. 100). Jeżeli u Silvermana model to „wszechogarniająca rama pozwalająca patrzeć na rzeczywistość" (Silverman 2012a; s. 31), to poznanie przez upodobnienie afektywne jest najszerszym modelem poznawczym, gdyż mówi także o instynkcie roztropności i rozwagi. Jest to według Maritaine'a ,podstawowy, najbardziej dostosowany do człowieka rodzaj poznania przez afektywne, czyli skłonnościowe upodobnienie" (Maritain 1988b; s. 100/101). Sama nasza skłonność do poznania musi być towarzyszem roztropności, realizacją rozważną.

Poznanie przez upodobnienie umystowe wynika, pisze Maritain, „z habitus właściwego człowiekowi o umyśle spekulatywnym, mędrcowi, czy uczonemu” (Maritain 1988b; s. 101). „Każdy habitus rodzi pewien stosunek do przedmiotu i pewne upodobnienie. W ten sposób umysł matematyka, czy metafizyka upodobnia się do spraw matematyki, czy metafizyki, a owo umysłowe upodobnienie dąży tylko do udoskonalenia i ułatwienia procesu poznania przez poznanie, przez pojęcia i wyobrażenia. Mamy tu poznanie przez upodobnienie umy- 
stowe do rzeczywistości, która może być ujęta $w$ pojęcia i dostosowana w akcie do umysłu ludzkiego" (Maritain 1988b; s. 101). Ważne jest w ogóle odczytywanie tu odniesienia do tego, „co więcej”. Uduchowienie poznania, uduchowienie wiedzy. Maritain ten problem podejmie w ostatnim upodobnieniu do rzeczywistości transcendentnej. Albert Menne, autor bardzo racjonalnego kompendium metodologicznego, konstruując swoje relacje „nauki jako nauczania” i „nauki jako badania” zamyka je ostatnim argumentem „G”, który określa jako „tło historyczne, społeczeństwo, współodpowiedzialność”, ale też może on „zawierać także pewne komponenty metafizyczne” i „daje się również interpretować jako coś boskiego, jako granica, kres. (Menne: 16) Tak więc znów jesteśmy zawsze obserwatorem ,atlasu wszechświata”, który musi zdać sobie sprawę ze swojej perspektywy badawczej.

Poznanie poetyckie. „Polega ono, pisze Maritain, na poznaniu przez efektywne upodobnienie do rzeczywistości jako niedajacej się ują́ w pojęcia ${ }^{1}$, gdyż uświadamiającej twórcze głębie podmiotu im samym; innymi słowy jest to poznanie do rzeczywistości stosownie do tego, jak ta ostatnia jest uwewnętrzniona w samej podmiotowości jako umysłowo płodnej egzystencji i jak jest dosięgana w konkretnej i egzystencjalnej harmonii z podmiotem jako podmiotem. [...] znajdując się, podobnie jak upodobnienie oparte na rozwadze, w linii tego, co możliwe w praktyce (nie w linii agibile, lecz w linii factibile), poznanie poetyckie niewątpliwie usposabia do kontemplacji i pełne jest kontemplacyjnych przebłysków natchnienia" (Maritain 1988b; s. 106). Mieczysław Krapiec thumaczy, że „agibile oznacza czynność człowieka jako taką, podczas gdy factibile jest używane na oznaczanie produktu czynności. Factibile wyraża to, co przez agibile ma się na zewnątrz ujawnić i trwać samo w sobie jako wytwór" (Krapiec; s. 30). „Mamy tu, pisze, do czynienia nie tyle z poznaniem, ile raczej w prawdziwym tego słowa znaczeniu z konstrukcją (twórczością) poznawczą. Jeśli bowiem akt poznania jest żywym stykiem podmiotu poznającego z przedmiotem, to podmiot musi w zasadzie sam uformować, skonstruować zastępczy obraz rzeczy. Utworzony obraz zastępczy jest odbiciem obiektywnego, aspektywnego stanu rzeczy" (Krapiec; s. 32). Jest to po prostu przedstawienie naszej wiedzy. Jeżeli na początku powiedzieliśmy o dwu ograniczeniach (właściwości obserwatora i pewnej obiektywnej możliwości postrzegania reprezentacji świata), to tu zastanawiam się, czy możemy więc dorzucić trzecie ograniczenie: ,utworze-

${ }^{1}$ Maritain, jak widzimy, użył tu wyróżnika czwartego obszaru poznania przez upodobnienie, myślę że dlatego, iż w pewnej przestrzeni dotyka tu wspólnej dla obu obszarów wyjątkowości człowieka poznającego. 
nie obrazu zastępczego obiektywnego stanu rzeczy". Chodzi mi o określenie „ograniczenie”. Kusi, aby użyć określenia „otwarcie”. Otwarcie na co? Otwarcie na tworzenie kultury naukowej, która sama w sobie będzie ,uniwersum poznawanym”. Krapiec pisze, że ,istotnym elementem poznania twórczego jest umiejętność konstruowania nowych pojęć - idei w stosunku do obranego przez siebie kryterium" (Krapiec; s. 33). Ludwik Hirszfeld pisze o przełomowym odkryciu Charles'a Nicolle, bakteriologa, laureata Nagrody Nobla, „pojęcia patologii bezobjawowej (nosicielstwa)”, które nazywa „największą rewolucją w dziedzinie bakteriologii od czasów Roberta Kocha” (Hirszfeld: 141): „Nie znam badacza, który by tak pragnął oddać głębię nie tylko swoich myśli, ale i przesłanek uczuciowych. W pracach swoich (Nicolle) daje ujście instynktowi poety-filozofa. O umysłowości klinicysty pisze Nicolle: Mózg jego powinien być jak gdyby lustrem: posiadać czułość $i$ wyrazistość, przy wyzbyciu sie przesqdów, idei wiernie przekazanych, idei szkoły." (Hirszfeld; s. 142). Nicolle w liście pożegnalnym (przed śmiercią) do Hirszfelda pisze: „(Potrafił Pan) zobaczyć w mojej pracy to, co jest rzeczywiście dziełem bliskim zarówno sztuce, jak i nauce.” (Hirszfeld; s. 143). A przecież dzieło Nicolle’a pomaga ratować nasze życie, bynajmniej nie w sensie poetyckim, a przeraźliwie realnym.

Poznanie przez upodobnienie do rzeczywistości jako niedajacej się ujać w pojęcia. Pod tym względem, wskazuje Maritain, „rzecz ma się podobnie, jak w przypadku doświadczenia poetyckiego", ale ta rzeczywistość tu jest pojmowana jako „ostateczny kres aktu poznania w jego doskonałej immanencji”. Powinniśmy zgodzić się, że poznając, badając naukowo, zmierzamy do jakiegoś, nie zawsze wyraźnie wyartykułowanego, kresu. To właśnie powinno nas skłaniać do pracy naukowej. Wielokrotnie wielu autorów nazywa to miłością poznania, która w ogóle jest przyczyną działania (Maritain 1988b; s. 107). Maritain rozróżnia te kresy zależnie od tego, czy chodzi o upodobnienie afektywne, czy upodobnienie umysłowe. W pierwszym, kres zbliża do mistycyzmu, nadprzyrodzonej kontemplacji. W drugim, „mamy do czynienia z kontemplacją naturalną, drogą pojmowania przed- czy pozapojęciowego dosięgającą rzeczywistości transcendentnej, która sama w sobie jest niewyrażalna ludzkim myślowym słowem" (Maritain 1988b; s. 108). Pedagogika, pedagogika specjalna. Poznajemy podmioty poznające. I poznając je, musimy oczywiście widzieć ich całość, pełnię w tischnerowskim „dramacie poznania”, takim samym, jak nasz dramat poznania (por. Tischner i Wojciechowski). Nie mogą być tylko i jakimiś przypadkami oligofrenicznymi, z zaburzeniami sensorycznymi, czy nieuleczalnymi przypadkami onkologicznymi. Pracuję z nimi od prawie 40 lat. Może, $\mathrm{z}$ trudem początkowo, ale ciagle coraz pewniej, widzimy ich zmierzanie do kre- 
su, a może ich pewność kresu transcendentnego, mistycznego. Pracujemy nad opisaniem tego. Jednak, jeśli idzie o inteligentną pewność tego kresu w skrajnej sytuacji granicznej, jaką jest pewna, niesprawiedliwa śmierć dziecka, przedstawia to Józef Binnebesel w swoich pracach, z których najważniejszą dla mnie jest ostatnia - Tanatopedagogika (Binnebesel 2010, 2012), w której umieszcza to ich poczucie mistycznego, transcendentnego kresu poznania na tle tego samego, najsilniejszych ludzkich umysłów. To jest wezwanie do pogłębiania, otwarcia perspektyw pedagogiki specjalnej.

To przedstawianie myśli, które kończę, miało ukazać uzasadnioną metodologicznie, a nawet konieczną metodologicznie, drogę poznania naukowego, mającą przekraczać modele.

Otto Speck pisze wyraźnie: „Istnieje niebezpieczeństwo, że zawężenie refleksji do kwestii czysto naukowych, lub technicznych uczyni ją powierzchowną (zobiektywizowana), oraz że pozostanie ona tylko w umyśle tego, który się nią zajmuje, skoro pytania o sens życia i miary wartości zostaną z niej wykluczone. Pojawia się [...] poważne niebezpieczeństwo zagubienia drugiej osoby, zlekceważenia jej świata i oddalenia od niej. [...] Stosunku do (człowieka) nie da się zredukować do zwykłych zależności przyczynowych, dostępnych zewnętrznemu obserwatorowi” (Speck: 28).

Jerôme Lejeune, genetyk, około 30 lat przed odczytaniem pełnej sekwencji DNA człowieka, uprzedził nas, że będziemy zaskoczeni brakiemjakiegoś, w sposób oczywisty widocznego, skoku wobec reszty żywych istot. Gdzie więc szukać wyjątkowości człowieka, pyta. I odpowiada: w miłości LUDZKIEJ i w poezji, która jest własnością tylko człowieka (Lejeune 1979, 1981, 1988).

Przystępując do obszaru pedagogiki specjalnej najpierw widzimy statyczny obraz „konstelacji” deprywacji, braków, dysfunkcji i ich skrupulatnych opisów. Gdy jednak zdobędziemy się na odwagę, wkroczymy w Kosmos człowieczeństwa, Poezji i Miłości ludzkiej (nie seksualizmu), w których wymiarze odnajdziemy na nowo siebie i uwierzymy, że prawo do poezji i miłości ludzkiej też i nam przynależy.

A jednak, ciągle trzeba przypominać.

Jak $\mathrm{w}$ tej perspektywie rozumieć doniesienie naukowe na konferencji badaczki, pedagoga, która referując swoją pracę z kilkunastoletnią niepełnosprawną dziewczynką dramatycznie zbuntowaną przeciw własnej płci w okresie przedpokwitaniowym, co w końcu jest znane, dziewczynki, jak pokazała referentka, bez żadnych chromosomowych i hormonalnych zaburzeń płciowych, w pewnym momencie przerywa referat i spoglądając na zegarek, informuje słuchaczy, że właśnie zaczęto w ramach eksperymentu transseksualizacji poda- 
wać dziewczynce testosteron. Jaki jest wyjściowy model tej badaczki i jaki kres transcendentny jej poznania?

\section{Bibliografia}

Binnebesel J. (2010), Tanatopedagogika jako próba zrozumienia inności-syndrom Pinokio, (w:) Obecność i Nieobecność. Sytuacja człowieka słabego we współczesnej cywilizacji (przyczynek do studium), pod red. zespołu PRTON KPS WNP UMK (Monika D. Filińska, B. Momot, A. Wojciechowski), WN UMK, Torun.

Binnebesel J. (2012), Tanatopedagogika - w doświadczeniu wielowymiarowości człowieka i śmierci, Wydawnictwo Adam Marszałek, Toruń.

Bocheński J. M. (1992, 1993), Współczesne metody myślenia, Wydawnictwo "W drodze", Poznań; (tłum. Stanisław Judycki - tyt. oryg. Die zeitgenössischen Denkmethoden, A. Francke AG Verlag, Bern 1954).

Gogacz M. (1991), Ku etyce chronienia osób - wokót podstaw etyki, Wydawnictwo Pallotinum, Warszawa.

Hirszfeld L. (1989), Historia jednego życia, PAX, Warszawa.

Krąpiec M. (1995), Dzieła VII; Metafizyka - zarys teorii bytu, red. wyd. KUL, Lublin (także: Krapiec M. A. (1978), Metafizyka. Zarys teorii bytu. wyd. 2 przejrzane poprawione, Lublin).

Lejeune J. (1988), Existe-t-il une morale naturelle?, [w:] „,Humanae vitae”: 20 Anni dopo. Atti dell II Congresso Internazionale di Teologia Morale, Roma, 9-12 novembre 1988, wyd. Ares, Milano (bez r. wyd.).

Lejeune J. (1979), L'origine de l'intelligence, Académie des Sciences Morales et Politiques, Séance du 14 mai 1979.

Lejeune J. (1981), La débilité de l'intelligence, Médicine de Paris 1981, 5, pp. 137-142.

Maritain J. (1988a), Podmiotowość człowieka (tytuł oryg. Court traite de l'existence et de l'existant, wyd. 2, Flammarion, Paris 1964, s. 101-138), [w:] tegoż, Pisma filozoficzne, Wydawnictwo ZNAK.

Maritain J. (1988b), Naturalne doświadczenie mistyczne i próżnia (tytuł oryg. Quatre essais sur l'esprit dans sa condition charnelle, nowe wyd. popr. i uzup. Paris, Alsatia 1956, s. 127-166) (w:) tegoż, Pisma filozoficzne Wydawnictwo ZNAK, Kraków.

Menne A. (1985), Wprowadzenie do metodologii. Elementarne ogólne metody naukowe pracy umysłowej w zarysie, [w:] Menne A., Bombik M., Olszewski T., Nieznański E. Z ogólnej metodologii nauk, wyd. Akademii Teologii Katolickiej, t. II serii Miscellanea Logica, Warszawa. 
Silverman D. (2012a), Interpretacja danych jakościowych, Wydawnictwo Naukowe PWN, Warszawa.

Silverman D. (2012b), Prowadzenie badań jakościowych, Wyd. Nauk. PWN, Warszawa.

Speck O. (2005), Niepetnosprawni w spoleczeństwie. Podstawy ortopedagogiki (tyt. oryg. System Heilpädagogik. Ein ökologisch reflexive Grundlegung); Gdańskie Wydawnictwo Psychologiczne, Gdańsk.

Tischner J. (1990, 2001, 2012), Filozofia dramatu, Éditions du Dialogue, Societété d'éditions internationales, Paris, 1990; także Wydawnictwo Znak, Kraków 2001, 2012.

Wojciechowski Andrzej, (2012), Pedagogika obecności, śladem Księdza Józefa Tischnera „Filozofii dramatu”, Wydawnictwo Akapit, Toruń.

\section{Cognition by the assimilation as an input into the model by David Silverman}

\section{Summary}

David Silverman presents a methodological perspective based on the belief that there are no neutral research problems and that the world we know, depending on the way in which it is represented. It is a theory of knowledge. I'm working scientically on space cognition by assimilation by Jacques Maritane'a as overall cognition appropriate also for special education.

Keywords: David Silverman, special education, theory of knowledge. 